\title{
P-RICH MICAS IN THE WEST KIMBERLEY LAMPROITES; CONTRASTS WITH KIMBERLITES AND OTHER MICACEOUS ALKALINE ULTRAMAFIC INTRUSIONS
}

A.L. Jaques

Bureau of Mineral Resources, GPO Box 378, Canberra, ACT 2601.

Mica is a ubiquitous phenocryst and/or groundmass phase in many alkaline ultrabasic rocks, particularly those belonging to the ultrapotassic suite, and clearly plays an important role in their petrogenesis. Previous studies have shown that micas from kimberlites, lamprophyres, lamproites and other potassic volcanics have a wide range of compositions, particularly in terms of their Ti and Al contents (Bachinski and Simpson 1984; review). Experimental studies have shown that phlogopitic mica is a near liquidus phase in a spectrum of hydrous potassic liquids over a wide range of temperature, pressure, oxygen fugacity, and volatile contents indicating that a number of variables control or influence the stability and composition of mica crystallising in mafic and ultramafic melts. Studies have shown, for example, that Ti solubility increases with temperature and oxygen fugacity and decreases with pressure (Tronnes et al 1985). Both bulk composition and the compositjon of the fluid phase also influence mica composition and stability, with the latter likely to be strongly influenced by the halogen content of the fluid phase. Jaques et al (1984) proposed that $F$ plays a major role in the petrogenesis of lamproites by l) combining with high $\mathrm{H}_{2} \mathrm{O}$ contents (low $\mathrm{CO}_{2}$ ) in the source region to yield silica-saturated rather than strongly undersaturated partial melts, and 2) enhancing the stability of phlogopite to higher T. This paper presents data on the halogen content of mica from the West Kimberley lamproites and various other ultrapotassic rocks including micaceous kimberlites from southern Africa with a view to establishing the importance of $F$ in the petrogenesis of the lamproite suite in contrast to kimberlite. The data show that F (and Ti) contents are higher in lamproite micas than kimberlites, commonly by up to an order of magnitude.
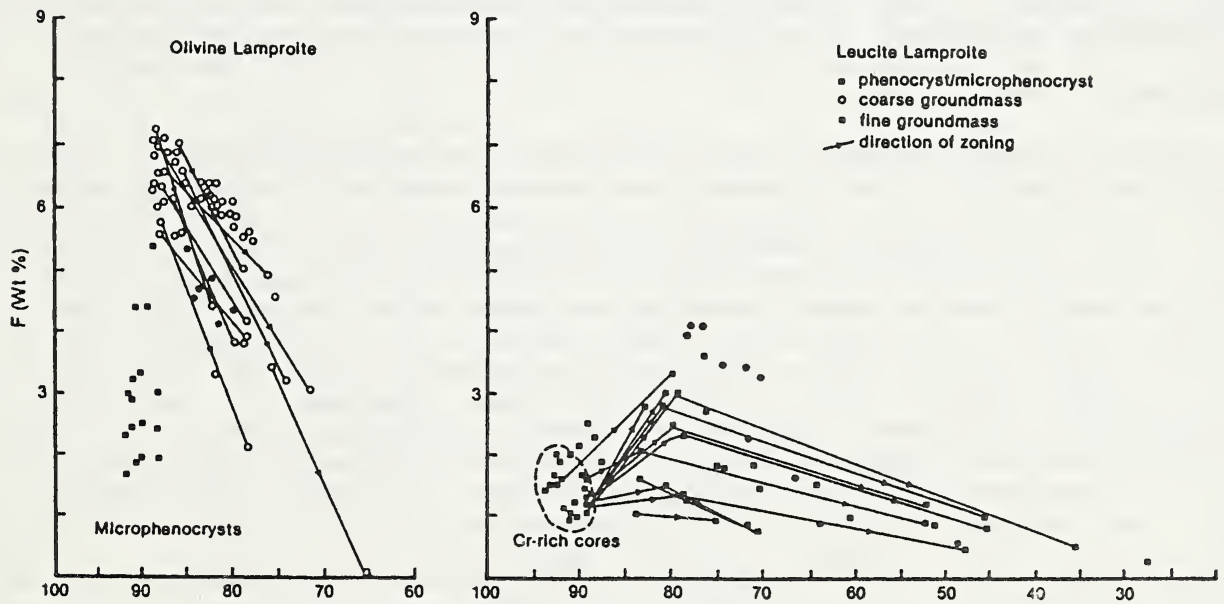

$100 \mathrm{Mg} /\left(\mathrm{Mg}_{\theta}+\mathrm{F}_{\theta}\right)$

Fig. 1. Variation of $F$ content in mica from the West Kimberley lamproites (after Jaques et al 1986). 
Data from nearly 500 whole rock analyses of the West Kimberley lamproites indicate that bulk rock $F$ contents range from 0.2 to 0.8 wt \% F with most containing 0.4 to 0.6 wt \% (Jaques et al 1986). Cl contents are low (av. 120-150 ppm) and F/Cl ratios high, averaging 41 in olivine lamproite and 17 in leucite lamproite. Phlogopites from the West Kimberley lamproites show a wide range in $100 \mathrm{Mg} /(\mathrm{Mg}+\mathrm{Fe})$ ratios $(92-27)$ and in $\mathrm{Ti}\left(1-12.2 \mathrm{wt} \% \mathrm{TiO}{ }_{2}\right)$ and $\mathrm{Al}$ contents $\left(1-12.8\right.$ wt $\% \mathrm{Al}_{2} \mathrm{O}_{3}$; Mitchell 1981; Jaques et al 1984, 1986; this work). F contents are high, typically 2 to 4 wt \% and ranging up to 7 wt \% (maximum value $=7.14$ wt \%) in $\mathrm{Ti}-\mathrm{rich}(5-7 \% \mathrm{TiO}$ ) phlogopite in olivine lamproites from Ellendale (Ellendale 9). The suite exhibits a broad correlation of $\mathrm{F}$ with TiO, content whereas phenocrysts typically show zoning trends of an initial increase in F with Ti content followed by a decrease (Fig. 1). Microphenocrysts and groundmass micas show a decrease in $\mathrm{F}$ with decreasing $\mathrm{Mg} /(\mathrm{Mg}+\mathrm{Fe})$ whereas mantles on Cr-rich cores in phenocrysts commonly show an initial increase in $\mathrm{F}$ followed by a decrease with $\mathrm{Mg} /(\mathrm{Mg}+\mathrm{Fe})$ as shown in Fig. 1. Apparent partition coefficients between phlogopite and melt, estimated from average $F$ contents in phenocrysts and/or microphenocrysts and whole rock F contents, range from 10-12 (9.512.7) in F-rich phenocrysts in olivine lamproite to much less than 10 (4-10) in the more F-poor phenocrysts in the more evolved leucite lamproites. An olivine-leucite lamproite from Oscar containing fresh glass has an apparent phlogopite-melt partition coefficient of 12.5. Cl contents in phenocryst and microphenocryst phlogopites are typically very low $(<100 \mathrm{ppm})$ and slightly higher in Fe-enriched rims and late crystallising groundmass flakes $(150-250 \mathrm{ppm})$. F/Cl ratios are typically higher than the bulk rocks. In addition to mica $\mathrm{F}$ is also hosted in potassic richterite which in leucite lamproites commonly contains 1-2 wt \% F. Where phlogopite and potassic richterite co-exist the mica, which crystallised first, invariably contains more F.

The Argyle lamproites (Atkinson et al 1984) are also characterised by high $F$ contents with the magmatic rocks containing 0.29 to 0.56 wt \% F (Jaques et al 1986 , this volume). Groundmass micas in these rocks (where present) contain up to $1.6 \mathrm{wt} \% \mathrm{~F}$ (typically 0,6-1.4 wt \%). Cl contents are low, typically $200 \mathrm{ppm}$ or less.

Data from other lamproite suites show that lamproites generally have high $F$ contents, e.g. Leucite Hills $=0.06-0.71$ (Kuehner et al 1981). Microprobe analyses (Foley et al in press; this work) show that the high bulk rock $F$ contents are reflected in their mica compositions. Magmatic olivine lamproites from Prairie Creek, Arkansas contain phlogopite with 4-6 wt \% F and 4-7 wt \% $\mathrm{TiO}_{2}$. Phenocryst micas from Leucite Hills lamproites exhibit a wide range in F contents which correlate with Ti content, and extend from comparatively low values ( 1 wt \% F, 2 wt $\% \mathrm{TiO}_{2}$ ) to high values ( 4 wt $\% \mathrm{~F}, 4-5$ wt $\% \mathrm{TiO}_{2}$ ) comparable to the mid-range of those found in the West Kimberley lamproites. Coarse micas in the Hills Pond peridotite, Kansas, have high $\mathrm{Ti}\left(5-6\right.$ wt \% $\left.\mathrm{TiO}_{2}\right)$ but low $\mathrm{F}$ contents (0.6-0.8 wt \%) and comparatively low $\mathrm{Mg} /(\mathrm{Mg}+\mathrm{Fe})$.

Data on halogen contents in kimberlite have been given by Paul et al 1976 and Wedepohl and Muramatsu (1979). The data show a large range with the highest values (up to 0.72 wt \% F) reported from the central Indian kimberlites. The value given by Paul et al (1976) for average kimberlite excluding central India $(0.165 \mathrm{wt} \%$ ) is very similar to the mean value of 0.19 wt \% given by Wedepohl and Muramatsu (1979). Data on the $\mathrm{F}$ contents of mica in kimberlites have been given by Paul et al (1976), Smith et al (1978, 1981), and Delaney et al (1980). Smith et al (1981) suggested that most unaltered micas which crystallised from unaltered kimberlites are low $1 \mathrm{n} \mathrm{C} 1$ ( $<0.05 \mathrm{wt}$ $\%$ and contain moderate $F(0.6-1$ wt \%). New data obtained for phenccryst and microphenocryst phlogopite ('type II') in micaceous kimberlites from southern Africa (De Beers, Newlands, Loxton, Dornkloof Sover, Southern Fissures, Belisbank) support this view. The kimberlite micas typically have higher $\mathrm{Al}\left(11-15 \% \mathrm{Al} \mathrm{O}_{3}\right)$, lower $\mathrm{Ti}(<4 \%$ $\left.\mathrm{TiO}_{2}\right)$, and substantially lower $\mathrm{F}(<1 \%)$ contents than mica in the olivine lamproites. Some of the highest $F$ contents $(0.8-0.9 \%)$ were found in rare Ti-rich $(3-4 \%$ TiO $)$ biotite ('type I') cores. For example, in the Dornkloof Sover dyke biotite cores $\left(\mathrm{Mg}_{66}\right)$ with $0.8-0.9$ wt \% F are rimmed by phlogopite ( $\mathrm{Mg}_{80}$ ) with similar F contents $(0.4-0.5$ wt \%) to that of the phlogopite phenocrysts $(0.4-0.5 \mathrm{wt} \%)$. Cl contents in most of the kimberlitic micas are low (typically 0.02-0.06 wt \%) although systematically higher contents (0.05-0.15 wt \%) were found in several of the kimberlites examined (De Beers, Benfontein Sill, Newlands). New whole rock F data for 4 of the kimberlites (Finsch $=0.04 \mathrm{wt} \%$, Loxton $=0.24 \mathrm{wt} \%$, Newlands $=0.12$ wt $\%$, and Dornkloop Sover $=0.09 \mathrm{wt} \%$ ) are all lower than typically found in lamproites. 
The data indicate that the $F$ content of early crystallised micas reflect the $F$ contents of their host rock. Lamproites have high F contents and lamproitic mica are F-rich; Ti- and F-rich micas appaer to be characteristic of lamproites. Kimberlites generally have lower $\mathrm{F}$ contents and their micas are much less F-rich, commonly by an order of magnitude. Micas from other potassic lamprophyres appear to have $F$ contents between kimberlites and lamproites. These differences in F contents are inferred to reflect differences in the $\mathrm{F}$ content of their mantle sources and it is suggested that the $F$ contents in ultrapotassic rocks and their early-formed micas are a measure of the degree of metasomatic enrichment of their source regions. F in the source regions of such rocks is inferred to be held mainly in mica. High $\mathrm{F}$ contents in the melt result in an enhanced stability of mica at high $T$ and $P$, as confirmed by experimental studies by Foley et al (in press) and thus have a significant bearing on the crystallisation of the magma.

\section{REFERENCES}

ATKINSON W.J., HUGHES $\dot{\mathrm{F} . E . ~ a n d ~ S M I T H ~ C . B . ~ 1984 a . ~ A ~ r e v i e w ~ o f ~ t h e ~ k i m b e r l i t i c ~ r o c k s ~ o f ~}$ Western Australia. In Kornprobst J. ed, Kimberlites 1: Kimberlites and Related Rocks, pp. 195-224. Elsevier, Amsterdam.

BACHINSKI S.W. and SIMPSON E.L. 1984. Ti-phlogopites of the Shaw's Cove minette: a comparison with micas of other lamprophyres, potassic rocks, kimberlites and mantle xenoliths. American Mineralogist 69, 41-56.

DELANEY J.S., SMITH J.V., CARSWELL D.A. and DAWSON J.B. 1980. Chemistry of micas in kimberlites and xenoiths -II. Primary- and secondary-textured micas from peridotitic xenoliths. Geochimica et Cosmochimica Acta 44, 857-872.

FOLEY S.F., TAYLOR W.R. and GREEN D.H. in press. The role of fluorine and oxygen fugacity in the genesis of the ultrapotassic rocks. Contributions to Mineralogy and Petrology.

JAQUES A.L., LEWIS J.D. and SMITH C.B. 1986. The kimberlitic and lamproitic rocks of Western Australia. Geological Survey of Western Australia Bulletin 132.

JAQUES A.L., LEWIS J.D., SMITH C.B., GREGORY G.P., FERGUSON J., CHAPPELL B.W. and MCCULLOCH M.T. 1984. The diamond-bearing ultrapotassic (lamproitic) rocks of the West Kimberley region, Western Australia. In Kornprobst J. ed, Kimberlites 1: Kimberlites and Related Rocks, pp. 225-254. Elsevier, Amsterdam.

KUEHNER S.M., EDGAR A.D. and ARIMA M. 1981. Petrogenesis of the ultrapotassic rocks from the Leucite Hills, Wyoming. American Mineralogist 66, 663-677.

MITCHELL R.H. 1981. Titaniferous phlogopites from the leucite lamproites of the west Kimberley area, Western Australia. Contributions to Mineralogy and Petrology 76, 243-251.

PAUL D.K., BUCKLEY F. and NIXON P.H. 1976. Fluorine and chlorine geochemistry of kimberlitès. Chemical Geology 17, 125-133.

SMITH J.V., BRENNESHOLTZ R. and DAWSON J.B. 1980. Chemistry of micas from kimberlites and xenoliths-I. Micaceous kimberlites. Geochimica et Cosmochimica Acta 42, 959-971.

SMITH J.V., DELANEY J.S., HERVIG R.L. and DAWSON J.B. 1981. Storage of $\mathrm{F}$ and $\mathrm{Cl}$ in the upper mantle: geochemical implications. Lithos 14, 133-147.

TRONNES R.G., EDGAR A.D. and ARIMA M. 1985. A high pressure-high temperature study of TiO solubility in Mg-rich phlogopite: implications to phlogopite chemistry. Geochimica et Cosmochimica Acta 49, 2323-2329.

WEDEPOHL K.H. and MURAMATSU Y. 1979. The chemical composition of kimberlites compared with the average composition of three basaltic magma types. In Boyd F.R. and Meyer H.O.A. eds, Kimberlites, Diatremes, and Diamonds: Their Geology, Petrology, and Geochemistry, pp. 300-312. American Geophysical Union Washington, D.C. 